\title{
Social dimensions of municipal sustainability: guidance for strategic planning
}

\author{
Natalia Vlasova*, and Anna Loginovskikh \\ Ural State University of Economics, 8 Marta Str., 62, 620144 Ekaterinburg, Russia
}

\begin{abstract}
Regional and urban sustainability no longer consider as an solely environmental or economic concern, but also incorporate social dimensions. However, the notions and indicators of social dimension of sustainability has not been very clearly defined. We linked social sustainability with the level of socio-economic well-being, equitable access to social service and quality of social capital. There are at least three types of municipalities in the Sverdlovsk region, based on the availability of certain social services and their dynamics. Analysis of strategic documents and policy actions of regional government demonstrate some positive shifts in social services availability, however regional differentiation on the demographic and economic indicators should also be taken in account. Gaps in the regional strategic planning system are identified and recommendations are formulated.
\end{abstract}

\section{Introduction}

The concept of sustainable development is complicated and, according to many authors, includes at least an interrelated triad - ecology, economy, and social aspects $[1,2]$. A number of scientists believe that it is necessary to consider not only the countries or regions sustainability, but also to focus on local territories that have their own specifics. Research on the sustainability of rural [3] and urban areas has become widespread [4, 5]. A number of authors link general sustainability criteria with local indicators of socio-economic development and propose a system of sustainable local development indicators $[6,7]$.

Many authors discuss conceptual framework of social sustainability, however the clear theoretical concept of social sustainability is still missing and it is an open and contested issue. The theoretical assumptions based on various theoretical approaches and assessment methods, but the generally accepted criteria are social homogeneity, equitable incomes, employment opportunities, access to goods and services $[8,9]$. T. Moroke, C. Schoeman and I. Schoeman also highlighted the importance of social and human capital, the quality of social services, and liveability indicators [10]. Sustainability is also linked to the inequality caused by differentially and disproportionally distributed resources, both geographically and among groups. E. Eizenberg, Y. Jabareen consider that the concept of safety is the fundamental part of sustainability in general and social sustainability in particular [11].

\footnotetext{
*Corresponding author: vnj@usue.ru
} 
Many scholars agree that the meaning of social sustainability could also include social capital and opportunities for its local development [12, 13]. Therefore, a number of scientists link social sustainability with the development of lifelong education: pre-school and school education, higher education and retraining. Agbedahin analyses the crucial interconnection between human development, education, sustainable development and finally education for sustainable development. It is emphasized that the mutual influence is very great, since education based on the sustainable development principles and goals may have a greater impact on the sustainability in the future than government programs and projects [14].

There are studies that prove a positive relationship between government recurrent expenditure on human capital development and the level of real output [15].

The sustainability discourse emphasizes the importance of institutional aspects and policy implementation of social development $[16,17]$.

Boström links social sustainability goals and procedural aspects of their achievement. For example, to provide access to social infrastructure, mobility, local services, facilities, green areas, and have an opportunity for learning and self-development it is necessary to provide an access to participation and decision making in different stages of the process and to assure social monitoring of the policy and planning [18, p.6].

The concepts of sustainability are based on different needs and interests and therefore require a lot of know-how in how to deal with different interests. Therefore, networks of cooperation designed to overcome political conflicts at different levels of government or between different stakeholders are basic for local sustainable development [19].

These challenges necessitating the rethinking and revision of current planning approaches and tools [20].

Scholars are trying to determine whether the principles of sustainable development are just a political agenda or whether they are integrated into government policies. For example, Saha and Paterson, based on survey in medium to large cities in the United States revealed in what extend local governments in the US are committed to the principles of sustainable development in their planning practices [21]. Also based on the results of a survey, Jepson Jr. claims that the public policies that provide individual opportunity and/or guide the behavior of individuals become an important component of sustainable social development [22].

It is important to understand how the goals of social sustainability and tools for it achieving are integrated into the municipal and the regional strategies.

\section{Materials and Methods}

Based on the assumption that social sustainability depends on social infrastructure and the availability of social services, at the first stage the provision of places in kindergartens for the population in the Sverdlovsk region municipalities was analysed. The density of preschool institutions in the municipalities of the Sverdlovsk region was also calculated. The data sources was the automated management system "E-services. Education" and data from the official website of the Federal state statistics service for the Sverdlovsk region and Kurgan region.

At the second stage, the system of strategic documents of the Sverdlovsk region was analysed from the point of view of implementing the principles of sustainable social development. Municipal strategies, which are published on the municipalities' official websites, were considered, as well as the Strategy of socio-economic development of the Sverdlovsk region for 2016-2030. When analyzing municipal strategies, attention was drawn to inter-municipal projects that are aimed at the development of social facilities: in the field of education, sports, health, etc. When considering the regional strategy, we 
focused on the policy and tools of spatial inequalities reduction. Projects on initiative budgeting of social services development, supported by the Sverdlovsk region government for 2018-2020 were also taken into account.

\section{Results and Discussion}

The educational environment is one of the components of a comfortable social milieu and one of the priorities of the "Concept of creating a comfortable social environment in the Sverdlovsk region until 2035". According to the "Strategy of the education development in the Sverdlovsk region for the period up to 2035", an important social problem in 2010 2016 was ensuring the availability of preschool education for children aged $3-7$ years.

This problem was solved by 2016 due to the state programs implemented in $2010-2015$ in the Sverdlovsk region, including "Development of the network of preschool educational organizations in the Sverdlovsk region" for 2010-2014, "Development of the education system in the Sverdlovsk region until 2020", "Implementation of the main directions of state policy in the construction complex of the Sverdlovsk region until 2020". As a result, 82.2 thousand additional places in preschool educational organizations were created. The next task is to achieve $100 \%$ accessibility of preschool education for children aged 2 months to 3 years by 2021 .

The Federal and regional programs for the education development and the passport of the regional project define the planned values of these indicators (Table 1).

Table 1. Government purposes for accessibility of the pre-school education in Sverdlovsk region

\begin{tabular}{|c|c|c|c|c|}
\hline Indicator & $\mathbf{2 0 1 7}$ & $\mathbf{2 0 1 8}$ & $\mathbf{2 0 1 9}$ & $\mathbf{2 0 2 0}$ \\
\hline $\begin{array}{c}\text { Accessibility of preschool } \\
\text { education for children aged 2 } \\
\text { months to 3 years, \% }\end{array}$ & 73.9 & 84.8 & 94.1 & 100.0 \\
\hline
\end{tabular}

However, despite regional achievements, it is necessary to understand the situation in each municipality and provide appropriate measures.

The program of the pre-school education development in the Sverdlovsk region includes three groups of municipalities. First, there are 19 municipalities, where availability is already fully secured. Secondly, in 17 municipalities, the problem should to solve by holding events in the current municipal system of preschool education (admission of children at the request of parents to groups for children aged 3 to 4 years, conversion of preschool groups to nursery, provision of short-term services). Finally, a more critical situation exists in 35 municipalities, which can only be resolved by building new facilities. It is planned to build 35 new pre-school buildings and 6 extensions to buildings, reconstruct 9 pre-school buildings, return 14 pre-school buildings to municipal pre-school education systems, and buy 4 pre-school buildings.

The analysis of the density of preschool institutions, which was defined as the number of institutions per thousand square $\mathrm{km}$., was based on the assumption that the low density of these institutions reduces their accessibility to the population, especially for municipalities with a large territory and an insufficiently developed communication system between settlements. The area served by a single preschool has significant territorial differences and depends on the distance of the municipality from Yekaterinburg and the Yekaterinburg agglomeration. The north part of the Sverdlovsk region is characterized by a low density of this service (Table 2). 
Table 2. Spatial accessibility of the pre-school education in Sverdlovsk region, 2019

\begin{tabular}{|c|c|c|}
\hline & $\begin{array}{c}\text { Density of placement } \\
\text { of children's } \\
\text { preschool } \\
\text { institutions, number } \\
\text { per thousand sq. km. }\end{array}$ & $\begin{array}{c}\text { The area of the } \\
\text { territory served } \\
\text { by one preschool, } \\
\text { km. }\end{array}$ \\
\hline $\begin{array}{c}\text { The core of Ekaterinburg agglomeration } \\
\text { (zone of } 30 \mathrm{~km}\end{array}$ & 134.5 & 7.4 \\
\hline $\begin{array}{l}\text { The fringe of Ekaterinburg agglomeration } \\
\text { (zone of } 60 \mathrm{~km} \text { from the core) }\end{array}$ & 12.4 & 80.4 \\
\hline $\begin{array}{l}\text { Northern administrative district of } \\
\text { Sverdlovsk region }\end{array}$ & 1.6 & 608.9 \\
\hline Sverdlovsk region, in average & 7.0 & 142.8 \\
\hline
\end{tabular}

The analysis of funds allocated from the regional budget in the framework of the regional competition for initiative budgeting showed the following. The government of the Sverdlovsk region initiated the competition in 2018. The amount of funding allocated for the implementation of projects remains insignificant for the entire period. Only about 9 million rubles were directed for this purpose in 2018, supporting 19 projects; just over 10 million rubles in 2019 were allocated among 23 projects; and just over 12 million rubles is planning to spend in 2020 . This is about $0.004 \%$ of the regional budget expenditure.

Analysis of municipal strategies shows a clear lack of inter-municipal cooperation projects, especially in the field of social services. Just several municipalities of the region included inter-municipal projects in their strategies. Such inter-municipal projects can be the only way to compensate for the shortage of social services and social infrastructure for municipalities with insufficient internal resources. Many practitioners note that this is due to the lack of the legal framework and institutions for the inter-municipal cooperation development at the Federal and regional levels.

\section{Conclusion}

1. The concept of regional and urban social sustainability should include not only the quantity of social services, but also their availability, including spatial accessibility. Spatial accessibility with the same quantitative indicators can be completely different for different part of the region, urban and rural areas, for municipal districts with a large territory and a poorly developed transport network between settlements. This is especially important for disabled people, the elderly, as well as for families with children - for those categories of population that most use such services.

2. Spatial heterogeneity at the intraregional level in the Russian Federation remains high and requires spatial planning measures. Most municipalities in the Sverdlovsk region continue to lose population.

3 . The system of strategic planning documents on municipal level should include intermunicipal projects for the social infrastructure facilities development. However, this requires creating a framework for the inter-municipal projects development at the regional level.

4. Social sustainable development needs an integrated social approach, which puts emphasis on a co-operative process between different interest groups on the municipal and regional levels. Participatory planning and budgeting tools are an effective mechanism for 
the social facilities and services expansion, however this still underutilized at the regional and municipal levels. It is necessary to expand the experience of participatory budgeting and to increase funding for these projects from the regional budget.

\section{Acknowledgements}

The article was prepared with the financial support of the RFBR of the research project No. 20-010-00824 "Incremental approach to the formation and implementation of socioeconomic development strategies for the Russian Federation regions of different hierarchical levels: uniform rules of strategizing".

\section{References}

1. Y. Shi, Sustainability, 11 (2019)

2. G. Munda, M. Saisana, Reg. Stud., 45 (2011)

3. Y. Liu, Land use policy, 74 (2018)

4. A. Wallis, A. Richards, K. O'Toole, B. Mitchell, Int. Int. J. Environ. Sustain. Dev., 6 (2007)

5. N. Dempsey, C. Brown, G. Bramley, Prog. Plan., 77 (2012)

6. A.Sodiq et al. J. Clean. Prod., 227, 972 (2019)

7. A. Mascarenhas et al. Ecol. Indic., 10 (2010)

8. N. Dempsey, G. Bramley, S. Power, C. Brown, Sustain. Dev., 19 (2011)

9. S. Vallance, H.C. Perkins, J. E. Dixon, Geoforum, 42 (2011)

10. T. Moroke, C. Schoeman, I. Schoeman, Sustain. Cities Soc., 48 (2019)

11. E. Eizenberg, Y. Jabareen, Sustainability, 9, 68 (2017)

12. M. Zhang, X. Zou, L. Sha, Sustainability, 11, 662 (2019)

13. L Diaconu., C. C. Popescu, EJSD, 5 (2016)

14. A. V. Agbedahin, Sustain. Dev., 27 (2019)

15. S. A. Oluwatobi, I. O. Ogunrinola, J. Sustain. Dev., 4 (2011)

16. B. Littig, E. Griessler. Int. J. Sustain. Dev., 8 (2005)

17. R. Jovovic, M. Draskovic, M. Delibasic, M. Jovovic, J. Int. Stud., 10, 255 (2017)

18. M. Boström, Sustain Sci. Pract. Pol., 8 (2012)

19. A. Dale, L. Newman, Community Dev J., 45 (2010)

20. M Davidson, Local Environ., 14 (2009)

21. D.Saha, R. G. Paterson, J Plan. Educ. Res., 28 (2008)

22. E. J. Edward Jr., J. Plan. Educ. Res., 23 (2004) 